\title{
DAMAGE ASSESSMENT AND CHEMICAL CHARECTERIZATION OF GLASS OBJECTS EXCAVATED FROM GADARA, NORTHERN JORDAN
}

\author{
Ramadan Abd-Allah a,b,c \\ a Conservation Dept., Faculty of Archaeology, Cairo University, Orman 12613, Giza , Egypt-rmdnabdalla@yahoo.com \\ b Faculty of Archaeology and Tourism, The University of Jordan, Amman 11942, Jordan \\ c Hamdi Mango Center for Scientific Research, The University of Jordan, Amman 11942, Jordan
}

KEY WORDS:Gadara, Glass, Diagnosis, Chemical characterization, XRF, SEM, Deterioration, Corrosion.

\begin{abstract}
:
During the excavation works carried out by the Department of Antiquities, at the archaeological site of Umm Qais/Gadara, Northern Jordan, from January 6 to February19, 2009, a considerable collection of glass objects of different typologies and colors were uncovered in a Roman cemetery. These glasses were characterized chemically by using X-ray fluorescence spectroscopy (XRF) and examined by scanning electron microscopy (SEM). The results indicated that these glasses are of soda-lime-silica type and correspond to the previously defined Levantine I glass group, and dated back to the Roman period (1st-4th Century AD). Furthermore, SEM investigation revealed that those glasses are completely corroded, and subjected to intensive deterioration. Therefore the preservation of those deteriorated glasses was important because of their archaeological and technological interests.
\end{abstract}

\section{INTRODUCTION}

The modern village of Umm Qais, ancient Gadara during the Roman Empire's occupation of Jordan, is situated $110 \mathrm{~km}$ north of Amman (Capital of Jordan) on a broad promontory 378 meters above sea level with a magnificent view over the Yarmouk River, the Golan Heights, and the lake Tiberia (Figs. $1,2)$. Gadara was one of the most brilliant ancient Greco-Roman cities of the Decapolise (Weber, 1989; Nielson, 1992).

In 2009, excavation works were carried out in the eastern area of the site representing the Roman tombs (Fig. 3). Excavations uncovered some important and magnificent architectural monuments at the site, such as rock-cut and built tombs in different shapes and structures, in which numerous remains of coins, bones, pottery objects, metal tools, and glass objects were found. Great collections of intact glass objects of different typologies and colors were uncovered from tombs no. 1and 3 (Fig.4). These glasses were recovered together with considerable collections of pottery lambs and metallic coins, which were dated with certainty to the 1 st-4th centuries AD. Typologically, they were dated back to Roman period in Jordan (1 st-4th cent. AD) (Abd-Allah, 2010). These corroded glass objects appeared to be a good example of freshly excavated glass, on which several first aid treatments could be carried out in the field.

It was stated that when glass is buried in a water-containing environment, the surface of the glass reacts chemically with the water. Additionally, the amount and type of reaction is affected by the composition of the glass and the $\mathrm{pH}$ of the surrounding liquid. It was generally accepted that several parameters influenced the archaeological glasses pathology during burial, like type of glass, burial conditions and the thermal history (Jackson et al., 2012). It is presently thought that a reaction is brought about by the diffusion of water (mainly through $\mathrm{H}^{+}$ cation exchange) into the glass and the migration of the alkali cations from the glass, leading to a silica-rich layer that is also reduced in density ((El-Shamy, 1973; El-Shamy et al., 1975). The alteration takes place at the surface, but the water also penetrates beyond the visible interface between the altered and pristine glass at a depth that is a function of glass polymerization. This reaction is especially effective in glasses that are rich in potassium.

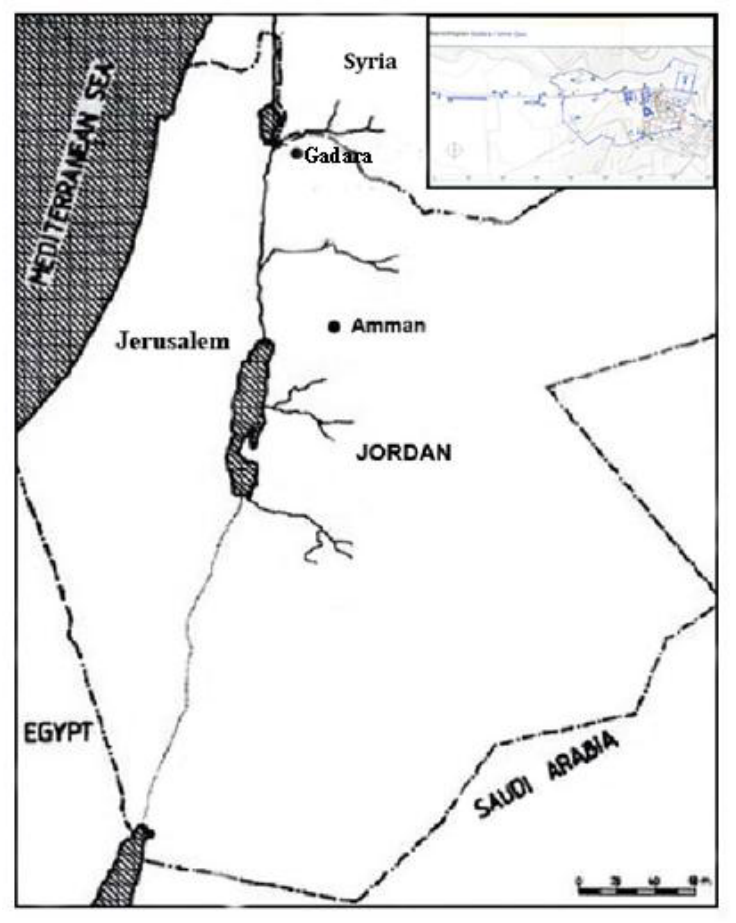

Figure 1: Map of Jordan indicating the site of Gadara/Umm Qais in Northern Jordan. 


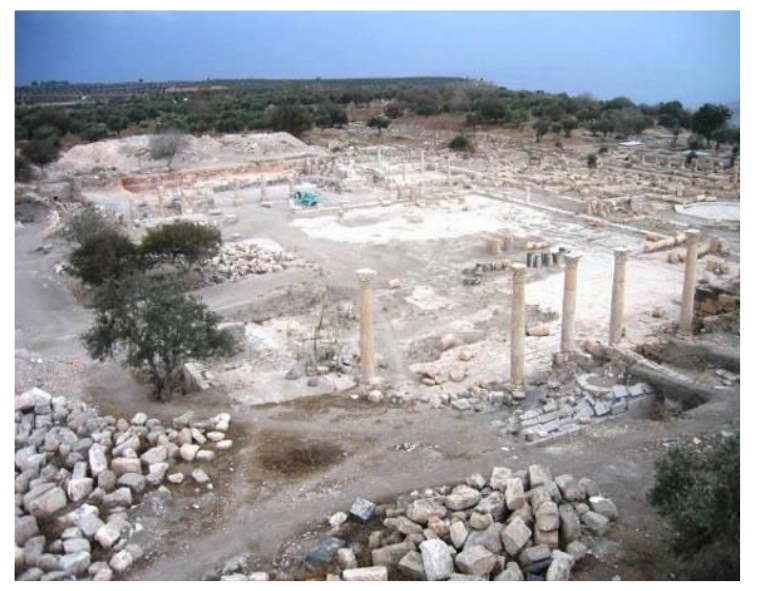

Figure 2: General view of the archaeological site of Gadara and some architectural remains.

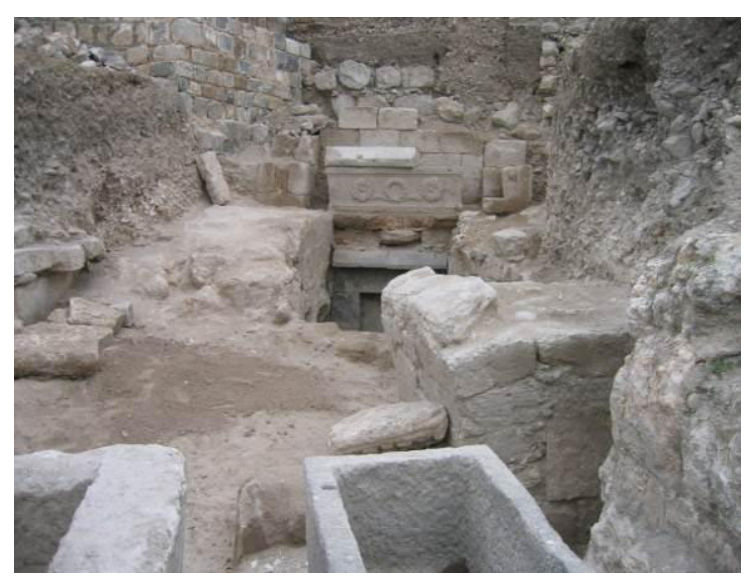

Figure 3: Roman cemetery excavated in the site, season 2009.

This newly formed silica-rich layer acts partly as a protective layer to the glass, slowing the rate of decay. The surrounding aqueous layer then becomes more highly alkaline with the increase in sodium and potassium ions. At $\mathrm{pH}$ 9, the silica- (and sometimes calcium-) rich layer is attacked and the process starts again. Thus, the interaction of glass with water involves, or causes, $\mathrm{pH}$ changes in the solution, which influences the type and rate of reaction (El-Shamy and Douglas, 1972; El-Shamy et al., 1972; Cox and Cooper, 1995; Sterpenich and Libourel, 2006; Gulmini et al., 2009; Rehren, 2008; Jackson et al., 2012; Abd-Allah, 2012).

However, the high content of soda $\left(\mathrm{Na}_{2} \mathrm{O}\right.$ or $\left.\mathrm{K}_{2} \mathrm{O}\right)$ leads to the process of leaching and corrosion of those glasses during burial in wet environment (Paul, 1977). In leached or corroded glass, there is an obvious change in the compositions of weathered crusts in comparison with the durable glass core of the same sample, i.e., sodium and potassium content decreases, whereas silica and calcium content increases (Newton and Davison, 1989).

The main objective of this study is firstly to characterize the chemical composition of those Roman glasses excavated from the archaeological site of Umm Qais/Gadara, secondly to assess the deterioration state in relation to burial environment and diagnosis the various aspects of decay by using visual observation and scanning electron microscopy examination.

\section{EXPERIMENTAL}

\subsection{Glass sampds}

A series of 24 glass fragment of different colors and typologies was collected, fully cleaned from the soiled deposits and weathering crusts, and prepared for the chemical analysis and SEM examination. Investigations includes these glass fragments addition to the five glass objects which could not be sampled but examined visually.

\subsection{Analytical techniques}

The glass samples were analyzed by the means of a Philips Magix pw 2424 X-ray fluorescence spectrometer (XRF), which uses the high-purity silica BCS-CRM 313/1 standard certified reference material from the Bureau of Analyzed Samples LTD, UK and works under vacuum, voltage $20-60 \mathrm{KV}$, current 5-150 $\mathrm{mA}$ and a Power limit of 4050 watt. Furthermore, microscopic and optical assessment was carried out. A scanning electron microscopy (SEM) model FEI Quant 200) operated in a secondary electron mode was used to examine the surface morphology and investigate the structure of encrustations and the underlying glass surface.

\section{RESULTS AND DISCUSSION}

\subsection{Chemical characterization}

The compositions of the previously described 24 glass fragments collected from the Roman tombs no. 1 and 3 as provided by the aid of X-ray fluorescence spectroscopy (XRF) are shown in Table 1. The results of the analyses indicate that the major components of the glass samples are: silica $\left(\mathrm{SiO}_{2}\right.$ avg. $67.85 \%)$, soda $\left(\mathrm{Na}_{2} \mathrm{O}\right.$ avg. $\left.14.98 \%\right)$, lime ( $\mathrm{CaO}$ avg. $\left.8.79 \%\right)$ and alumina $\left(\mathrm{Al}_{2} \mathrm{O}_{3}\right.$ avg. 2.97\%). They were also characterised by low contents of potash $\left(\mathrm{K}_{2} \mathrm{O}\right.$ avg. $\left.0.76 \%\right)$ and magnesia $(\mathrm{MgO}$ avg. $0.51 \%$ ). Therefore, these glasses can be classified as sodalime-silica $\left(\mathrm{Na}_{2} \mathrm{O}-\mathrm{CaO}-\mathrm{SiO}_{2}\right)$ glass, and correspond to the previously defined Levantine I glass group, the common type of ancient glass for more than three thousand years (Freestone, 2002, 2005, 2006; Foy et al., 2003; Tite et al., 2006; Schibille et al, 2008; Foster and Jackson, 2009; Abd-Allah, 2010).

This composition revealed that the main raw materials from which these glasses were manufactured were Levantine coastal sand as a source of silica, natron (from Wadi Natrun in Egypt) as a source of alkali soda, and lime (which is already present as impurity or shell fragments in the Levantine coastal sands) as a source of calcium (Abd-Allah, 2010). However, no evidence for a local primary production of raw glass (the preparation of fresh glass from its raw materials through fritting and melting) or a secondary production (the preparation of a quantity of hot glass by melting the primary glass in crucible, processing and finishing it into glass artefacts ) at these sites has been found to date. It was stated that glass production in the first millennium $\mathrm{AD}$ was divided between a relatively small number of workshops that made raw glass and a large number of secondary workshops that fabricated vessels. During the Roman and later periods, glass was produced from its raw materials in massive tank furnaces in a limited number of glass production centres (potentially in the Levantine area). The unformed chunks of raw glass originating from these furnaces were then re-melted to produce glass vessels at a larger number of glass working centres (Freestone et al., 2008). According to Abd-Allah (2010) 
raw glass chunks were imported to secondary production centres in Northern Jordan (such as Beit Ras) for local reworking in order to produce glass vessels in large quantities.

The high content of manganese oxide in samples 1 and $2(\mathrm{MnO}$ $0.54 \%$ and $0.32 \%$ respectively) indicate that manganese was intentionally used as colorizing agent in the form of $\left(\mathrm{Mn}^{3+}\right)$ ion to color the glass purple or violet. Whereas in all other transparent and colorless samples, manganese was used as decolorizing agent in the form of $\left(\mathrm{Mn}^{2+}\right)$ ion which acts as an oxidizing agent and converts the iron from its reduced state $\left(\mathrm{Fe}^{2+}\right.$, which is a strong greenish blue colorant) to an oxidized state $\left(\mathrm{Fe}^{3+}\right.$, which has a yellowish, but much less intense, color) (Jackson, 2005; AbdAllah, 2009).

\subsection{Visual and microscopic investigation}

As shown in Figure 3, some uncovered glass objects were found intact but suffering from different deterioration phenomena, the others were found completely fragile, broken down into several fragments and great area of their bodies was missed. Both the inner and outer surfaces of the glasses completely are corroded and covered with thin, milky layers of corrosion products. Eventually these layers separate slightly and, being of different and irregular thickness, refract light differently, given a colored effect known as iridescence. The layers became extremely fragile and peel off in very thin, onion skin-like pieces.

All the glass objects were found wet and covered with thick, hard layers of salty soiling and dirt, which strongly adhered to the glass surface. Moreover, the interior if the glasses were filled with a hard lump of soiling and dirt (Figs. 4, 5). Scanning electron microscopy examination of glass samples reveals that glass was completely corroded. It was observed that deterioration proceeding from the surface to the interior. In most cases large areas of the weathering crusts are destroyed, rich in dissolution voids and losses its glassy nature. Other aspects of deterioration were observed such as formation of weathering crusts, calcareous salt growing, soiled deposits covered glass surface, cracking and pitting of corroded surface (Fig. 6).

\subsection{Burial conditions assessment}

Inside the rock-cut tombs numbered 1 and 3(Fig.3 and 4), the mentioned glass objects were buried together with other bony, metallic and pottery remains in a damp, cohesive, salty, calcareous clay soil ( Soil moisture content $=6 \%$; $\mathrm{PH}$ value $=$ 8.4; Salinity $(\mathrm{EC})=3.4 \mathrm{~m} . \mathrm{mohs} / \mathrm{cm}^{-1}$; Density $=2.6 \mathrm{gm} / \mathrm{cm}^{3}$; Porosity $=60 \%$ ). Under these conditions, the glass has been broken down. Furthermore, it has been subjected to very intensive chemical deterioration; the flux is leached out preferentially to the silica, and the corrosion process is continues. It has been stated that the damp soil is most attack of glass rather than the dry one. Moreover, changes will resume as The complicated problem that emerged during excavation work is that these tombs have been in previous years subjected to acts of digging or theft in a random manner; resulting in a scattering of glass objects and artifacts pieces randomly, and were found to overlap with many other materials in a state of weakness. Corroded glass is sensitive to moisture and should be stored in as stable an environment as possible. Ideally, the relative humidity should be $40 \%$ or less (Singley, 1981; Scichilone, 1995; Abd-Allah, 2007). In a alkali- rich glass sodium and potassium are slightly soluble in some glass compositions. In the presence of high relative humidity, these components can be leached out to the surface of the glass where they are converted to carbonates. These carbonates attract moisture, and small droplets of water begin to appear on the surface of glass; hence, the name weeping glass. The leaching process causes tiny cracks to appear in the glass, and eventually the glass can be become opaque with small surface flaking. Further leaching and droplets formation will be stopped if the glass is kept at a relative humidity below $40 \%$. If the storeroom is very damp, it may be necessary to pack glass in airtight container with silica gel. Furthermore, glass objects should be stored in a suitable boxes or cardboard containers. In addition to artifacts, supplementary scientific data, specimens, and samples are also in need of curatorial care. So those materials were packaged and identified separately from other artifact.

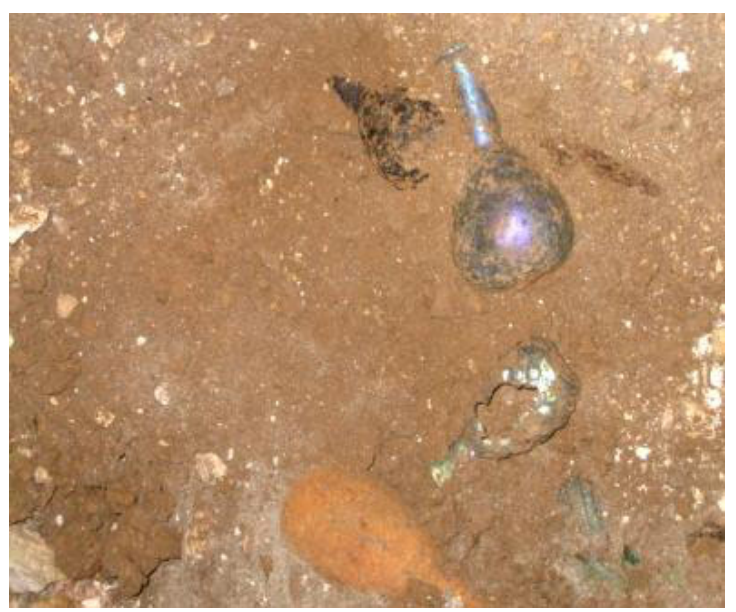

Figure 4: Buried glass objects uncovered in tomb no. 3 together with other numerous finds, season 2009 .

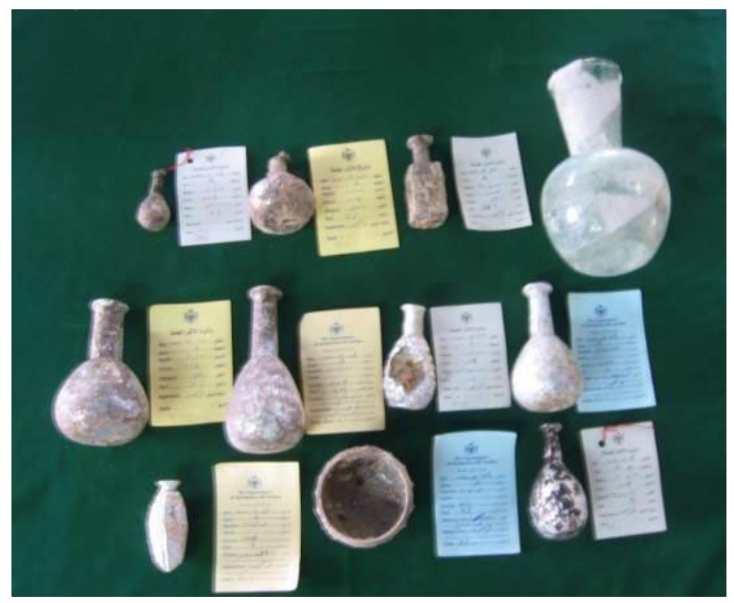

Figure 5: Glass objects after lifting from burial environment and first aid treatment. 


\begin{tabular}{|c|c|c|c|c|c|c|c|c|c|c|c|c|c|c|c|c|}
\hline \multirow[t]{2}{*}{ Sn. } & \multirow[t]{2}{*}{ Form style } & \multirow{2}{*}{ Color } & \multicolumn{13}{|c|}{ Oxides (wt.\%) } & \multirow{2}{*}{$\begin{array}{c}\text { Total } \\
\%\end{array}$} \\
\hline & & & $\mathrm{SiO}_{2}$ & $\mathrm{Na}_{2} \mathrm{O}$ & $\mathrm{K}_{2} \mathrm{O}$ & $\mathrm{CaO}$ & $\mathrm{Al}_{2} \mathrm{O}_{3}$ & $\mathrm{MgO}$ & $\mathrm{MnO}$ & $\mathrm{Fe}_{2} \mathrm{O}_{3}$ & $\mathrm{PbO}$ & $\mathrm{TiO}_{2}$ & $\mathrm{P}_{2} \mathrm{O}_{5}$ & $\mathrm{SO}_{3}$ & $\mathrm{Cl}_{2} \mathrm{O}$ & \\
\hline 1 & Small flask & Yellowish green & 67.65 & 15.12 & 0.95 & 8.90 & 2.55 & 0.80 & 0.54 & 0.64 & 0.07 & 0.08 & 0.21 & 0.09 & 0.91 & 98.51 \\
\hline 2 & Long- necked bottle & Yellowish green & 67.09 & 14.80 & 0.87 & 8.78 & 3.46 & 0.49 & 0.32 & 0.48 & 0.09 & 0.11 & 0.16 & 0.13 & 0.77 & 97.55 \\
\hline 3 & Thin-walled vessel & Colorless & 67.42 & 14.97 & 0.76 & 8.82 & 3.47 & 0.47 & 0.06 & 0.53 & 0.06 & 0.13 & 0.13 & 0.12 & 0.82 & 97.76 \\
\hline 4 & Small beaker & Greenish blue & 67.36 & 14.69 & 0.71 & 8.93 & 3.02 & 0.51 & 0.03 & 0.52 & 0.06 & 0.07 & 0.11 & 0.13 & 0.96 & 97.10 \\
\hline 5 & Long- necked bottle & Greenish blue & 67.71 & 15.11 & 0.61 & 8.46 & 2.81 & 0.45 & 0.05 & 0.55 & 0.10 & 0.11 & 0.17 & 0.09 & 0.82 & 97.04 \\
\hline 6 & Small beaker & Light blue & 68.77 & 15.00 & 0.69 & 8.57 & 2.74 & 0.50 & 0.03 & 0.46 & 0.07 & 0.12 & 0.13 & 0.10 & 0.94 & 98.12 \\
\hline 7 & large bottle & Light blue & 67.48 & 14.49 & 0.76 & 8.89 & 3.10 & 0.48 & 0.04 & 0.53 & 0.05 & 0.09 & 0.11 & 0.08 & 0.92 & 97.02 \\
\hline 8 & Small flask & Yellowish green & 68.34 & 14.77 & 0.71 & 9.03 & 2.82 & 0.45 & 0.05 & 0.52 & 0.02 & 0.09 & 0.17 & 0.18 & 0.73 & 97.88 \\
\hline 9 & Small flask & Greenish blue & 67.86 & 15.22 & 0.74 & 8.76 & 3.19 & 0.56 & 0.02 & 0.44 & 0.03 & 0.10 & 0.12 & 0.12 & 0.85 & 98.01 \\
\hline 10 & Long- necked bottle & Yellowish green & 68.69 & 15.13 & 0.68 & 8.90 & 2.83 & 0.49 & 0.04 & 0.47 & 0.04 & 0.09 & 0.11 & 0.08 & 0.83 & 98.38 \\
\hline 11 & Small flask & Greenish blue & 67.14 & 15.21 & 0.69 & 8.93 & 2.75 & 0.52 & 0.03 & 0.47 & 0.07 & 0.03 & 0.14 & 0.11 & 0.82 & 97.04 \\
\hline 12 & Small beaker & Light blue & 68.95 & 15.54 & 0.64 & 8.34 & 2.67 & 0.54 & 0.02 & 0.53 & 0.04 & 0.09 & 0.11 & 0.15 & 0.94 & 98.35 \\
\hline 13 & Thin- walled vessel & Greenish blue & 68.45 & 15.32 & 0.73 & 8.65 & 2.93 & 0.55 & 0.04 & 0.43 & 0.04 & 0.10 & 0.28 & 0.13 & 0.84 & 98.48 \\
\hline 14 & Small flask & Greenish blue & 67.43 & 14.91 & 0.74 & 8.68 & 3.18 & 0.47 & 0.03 & 0.48 & 0.08 & 0.11 & 0.16 & 0.11 & 0.65 & 97.03 \\
\hline 15 & long- necked bottle & Light blue & 68.44 & 14.56 & 0.92 & 8.79 & 2.82 & 0.45 & 0.05 & 0.52 & 0.02 & 0.09 & 0.17 & 0.18 & 0.73 & 97.74 \\
\hline 16 & Thin- walled vessel & Light blue & 66.99 & 14.63 & 0.77 & 8.88 & 2.94 & 0.58 & 0.04 & 0.54 & 0.08 & 0.13 & 0.19 & 0.12 & 0.83 & 96.72 \\
\hline 17 & Small flask & Light blue & 67.01 & 15.14 & 0.82 & 8.96 & 3.04 & 0.52 & 0.04 & 0.45 & 0.03 & 0.06 & 0.16 & 0.10 & 0.80 & 97.13 \\
\hline 18 & Thick- walled vessel & Yellowish green & 67.29 & 14.98 & 0.89 & 8.94 & 3.09 & 0.61 & 0.03 & 0.56 & 0.05 & 0.10 & 0.12 & 0.09 & 0.71 & 97.46 \\
\hline 19 & Long- necked bottle & Yellowish green & 67.38 & 15.10 & 0.68 & 9.02 & 3.33 & 0.49 & 0.04 & 0.55 & 0.11 & 0.08 & 0.34 & 0.09 & 0.69 & 97.90 \\
\hline 20 & Small beaker & Light blue & 68.05 & 15.02 & 0.84 & 8.75 & 2.72 & 0.49 & 0.03 & 0.53 & 0.07 & 0.08 & 0.13 & 0.14 & 0.82 & 97.67 \\
\hline 21 & Small flask & Light blue & 68.54 & 14.75 & 0.81 & 9.00 & 2.92 & 0.42 & 0.05 & 0.56 & 0.08 & 0.09 & 0.24 & 0.16 & 0.78 & 98.40 \\
\hline 22 & Small flask & Greenish blue & 68.95 & 15.10 & 0.68 & 8.54 & 2.69 & 0.50 & 0.04 & 0.53 & 0.06 & 0.09 & 0.15 & 0.14 & 0.81 & 98.28 \\
\hline 23 & Thin- walled vessel & Greenish blue & 67.42 & 14.97 & 0.76 & 8.82 & 3.47 & 0.47 & 0.06 & 0.53 & 0.06 & 0.13 & 0.13 & 0.12 & 0.82 & 97.76 \\
\hline 24 & Long- necked bottle & Light blue & 68.07 & 15.08 & 0.80 & 8.85 & 2.75 & 0.43 & 0.06 & 0.57 & 0.09 & 0.12 & 0.16 & 0.12 & 0.81 & 97.91 \\
\hline \multicolumn{3}{|c|}{ Avg.\% } & 67.85 & 14.98 & 0.76 & 8.79 & 2.97 & 0.51 & 0.07 & 0.54 & 0.06 & 0.09 & 0.16 & 0.12 & 0.81 & 97.71 \\
\hline
\end{tabular}

Table 1: Chemical composition of the selected glass samples obtained by XRF.
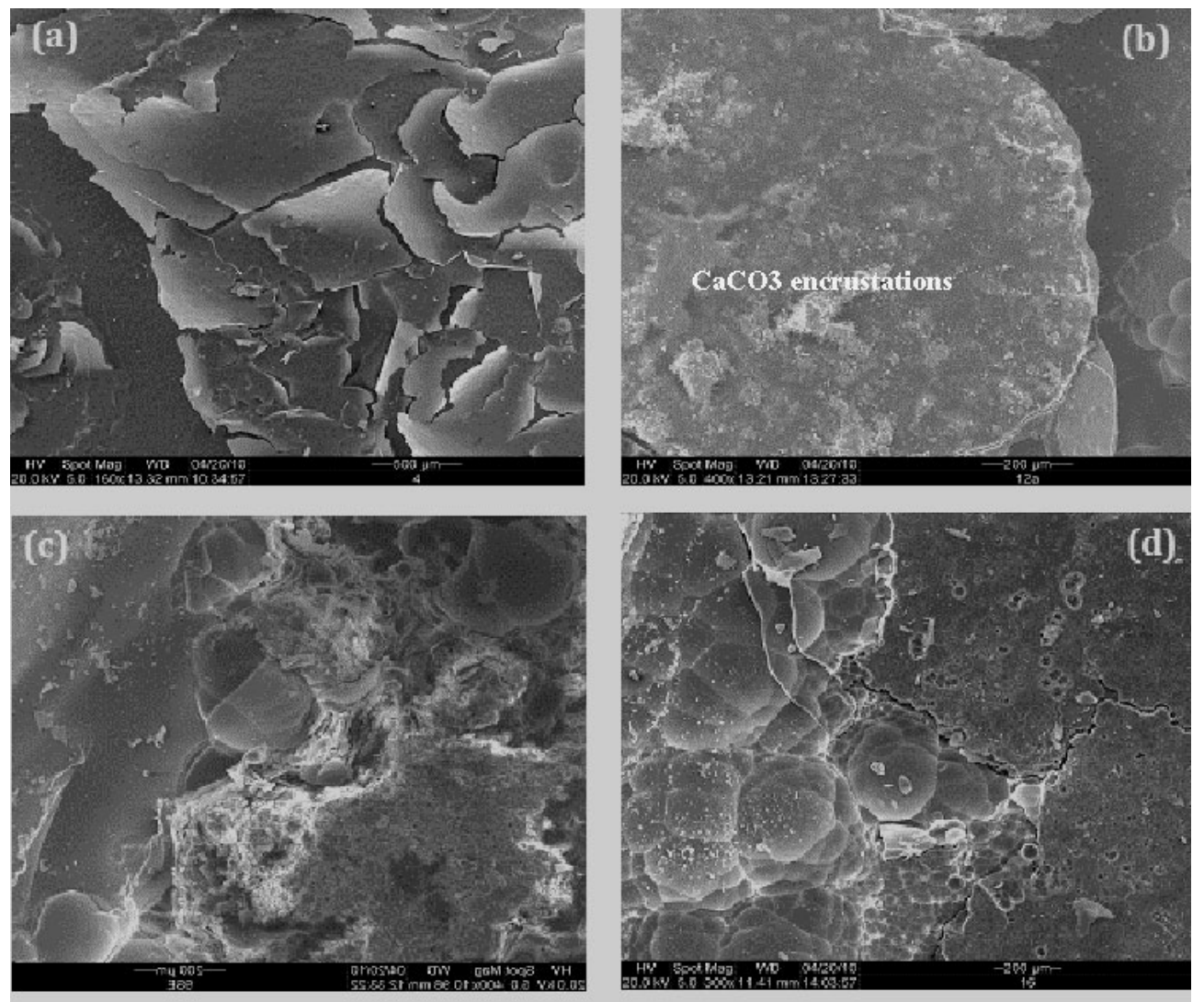

Figure 6: Secondary electron images of damaged glass samples showing the aspects of (a) formation of weathering crusts, (b) formation of calcium carbonate encrustations, (c) soiled deposits covered glass surface, (d) cracking and pitting of corroded surface, large areas of the weathering crusts be destroyed, rich in dissolution voids and losses its glassy nature. 


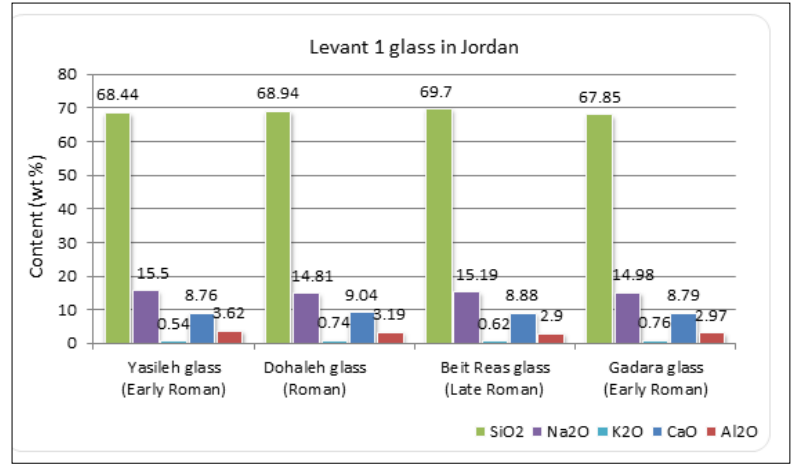

Figure 7: Levantine1 glasses from the Roman sites of Yasieleh, Dohaleeh and Beit Ras) compare with glass from Gadara in Northern Jordan. (Data of Abd-Allah 2010, 2012.

\section{CONCLUSION}

The results of the chemical analyses indicate that the glass does not show a clear distinction in terms of chemical composition between the Roman glass from Umm-Qais/ Gadara and the other Roman sites in Northern Jordan. The resulting data shows that the analysed samples are examples of soda-lime-silica glass, with natron used as flux, which was probably mostly obtained from Wadi Natrun in Egypt. Lime or calcium carbonate was certainly unintentionally present in the composition, due to the use of lime-rich quartz sand from the Syro-Palestinian or Levantine coasts; thus, calcium carbonate was incorporated with the sand rather than added as a separate component (Hatton et al., 2008). All the analysed glasses correspond to the previously defined Levantine I glass group (Fig. 7).

Buried glass mostly found in bad condition and subjected to intensive corrosion and other deterioration aspects such as pitting, cracking, encrustation, dulining and salt crystallization . So glass found dry should be kept dry as well. Dry pieces of glass should be packed in a rigid container which is well padded with acid-free tissue, and a layer of moisture-absorbing silica gel should be placed in the bottom of the container before putting in the padding to prevent the glass from further corrosion. Glass should be stored in as stable an environment as possible. Ideally, the relative humidity should be $40 \%$ or less.

\section{ACKNOWLEDGEMENTS}

The author gratefully acknowledge the Department of Antiquities of Jordan for their support. Great thanks to both Mr. Salama Fayad and Mr Nasr al-Zoubi as well as their excellent team members and local workers who do their bests in the work field at Umm Qais archaeological site. Gratitude also is to Hamdi Mango Center for Scientific Research (HMCSR), The University of Jordan for their support among the JOCHERA, (FP7 project) "Jordan Conservation of Cultural Heritage" funded by the European Union 2011.

\section{REFERENCES}

Abd-Allah, R., 2007. Stabilization and treatment of corroded glass objects displayed in the museum of Jordanian heritage. Mediterranean Archaeology and Archaeometry 7 (2), PP. 19-28.
Abd-Allah, R., 2009. Solarization behavior of manganesecontaining glass: An experimental and analytical study. Mediterranean Archaeology and Archaeometry 9 (1), pp. 37-53.

Abd-Allah, R., 2010. Chemical characterization and manufacturing technology of late Roman to early Byzantine glass from Beit Ras/Capitolias, northern Jordan. Journal of Archaeological science 37 (8), pp. 1866-1874.

Abd-Allah, R., 2012. Chemical cleaning of soiled deposits and encrustations on archaeological glass: A diagnostic and practical study. Journal of Cultural Heritage, doi:10.1016/j.culher. 2012.03.010 (in press).

Cox, G., Cooper, G., 1995. Stained glass in York in the midsixteenth century: analytical evidence for its decay. Glass Technology 36, pp. 129-34.

Cronyon, J., 1990. The elements of archaeological conservation, TJ Press, Cornwal,UK.

El-Shamy, T., Lewins, J., Douglas,R., 1972. The dependence on the $\mathrm{pH}$ of the decomposition of glasses by aqueous solutions. Glass Technology 13, pp. 81-87.

El-Shamy, T., 1973. The rate-determining step in the dealkalisation of silicate glasses. Physics and Chemistry of Glasses 14, pp. 18-19.

El-Shamy,T., Douglas, R., 1972. Kinetics of the reaction of water with glass. Glass Technology 13, pp. 77-80.

El-Shamy,T., Morsi, S., Taki-Eldin,H., Ahmed, A., 1975. Chemical durability of $\mathrm{Na}_{2} \mathrm{O}-\mathrm{CaO}-\mathrm{SiO}_{2}$ glasses in acid solutions. Journal of Non-Crystalline Solids 19, pp. 241-50.

Freestone, I., 2006. Glass production in Late Antiquity and the Early Islamic period: a geochemical perspective, Geomaterials in Cultural Heritage, M. Maggetti, B. Messiga (Eds.), Geological Society of London Special Publication 2006, 257, PP. 201-216.

Freestone, I., 2005. The provenance of ancient glass through compositional analysis, P. Vandiver, J. Mass, A. Murray (Eds.): Materials Issues in Art and Archaeology, VII, (Mater.Res.Soc.Symp. Proc.852, Warrendale, PA (2005) pp. O08.1.1-008.1.13

Foster, H., Jackson, C., 2009. The composition of 'naturally coloured' late Roman vessel glass from Britain and the implications for models of glass production and supply, Journal of Archaeological Science (36) pp. 189-204.

Foy, D. (et al.), 2003. Caractérisation des verres de la fin de l'Antiquité en Méditerranée occidentale: l'émergence de nouveaux courants commerciaux, D. Foy, M-D. Nenna, (Eds.): Échanges et commerce du verre dans le monde antique. Actes du colloque de l'AIHV, Aix-en-Provence et Marseille, juin 2001, Monographies Instrumentum, 24, Monique Mergoil, Montagnac 2003, pp. 41-85.

Freestone, I. (et al.), 2002. Byzantine and early Islamic glassmaking in the Eastern Mediterranean: production and distribution of primary glass, G. Kordas (Ed.): Hyalos -Vitrum Glass. History, Technology and Conservation of glass and 
vitreous materials in the Hellenic World. 1st International conference Rhodes - Greece 1-4 April 2001. Athens, pp. 167174.

Freestone, I., Jackson, E., Tal, O., 2008. Raw glass and the production of glass vessels at late Byzantine Apollonian-Arsuf, Israel. Journal of Glass Studies 50, pp. 67-80.

Gulmini, M, Pace, M., Ivaldi, G., Ponzi, M., Mirti, P., 2009. Morphological and chemical characterization of weathering products on buried Sasanian glass from central Iraq. Journal of Non-Crystalline Solids 351, pp. 613-21.

Hatton, G., Shortland, A., and Tite, M., 2008. The production technology of Egyptian blue and green frits from second millennium BC Egypt and Mesopotamia. Journal of Archaeological Science 35, pp. 1591-1604.

Jackson, C., Greenfild, D., Howie, L., 2012. An assessment of compositional and morphological changes in model archaeological glass in acidic matrix. Archaeometry 54 (3) pp. 489-507.

Newton, R. and Davison, S., 1989. Conservation of glass, 1st edition, Butterworth, London.

Nielson, H., 1992. Svend Gadarenes in Anchor Bible Dictionary, vol. 2, D.N. Freedman (Ed.), New York: Doubleday.

Paul, A. , 1977. Chemical durability of glass; Thermodynamic approach. Journal of Material Science 12, pp. 2246-2268.

Rehren, Th., 2008. A review of factors affecting the composition of early Egyptian glasses and faience: alkali and alkali earth oxides. Journal of Archaeological Science 35, pp. 1345-1354.

Scichilone,G.,1995. On- site storage of finds. In Conservation on archaeological excavations, ICCROM , Rome, pp. 67-69.

Sterpenich, J., Libourel, G., 2006. Water diffusion in silicate glasses under natural weathering conditions: evidence from buried medieval stained glasses, Journal of Non-Crystalline Solids 352, pp. 5446-5451.

Schibille, N., Marii, F., Rehren, Th., 2008. Characterization and provenance of late antique window glass from the petra church in Jordan, Archaeometry 50 (4) pp. 627-642.

Tite, M., Shortland, A., Maniatis, Y., Kavoussanaki, D., Harris, S., 2006. The composition of the soda-rich and mixed alkali plant ashes used in the production of glass. Journal of Archaeological Science 33, pp. 1284-1292.

Weber, T., 1989. Umm Qais - Gadara of the Decapolis Amman, Economic Press Co . 